\title{
tolentili

\section{Influence of Dayak Onion Extract Concentration (Eleutherine palmi folia (L.) Merr) and Length Storage on Weight Decrease, Haugh Unit, and Albumen pH of Duck Egg}

\author{
Aam Gunawan*, Muhammad Irwan Zakir, Raga Samudera, Siti \\ Dharmawati, and Muhammad Rasyidi
}

Animal Husbandry Study Program, Faculty of Agriculture, Universitas Islam Kalimantan MAB Banjarmasin, Indonesia

\begin{abstract}
The purpose of this study was to study the effect of immersion on dayak onion extract and storage time and the interaction of these two factors on decreasing of egg weight, haugh unit value and albumen $\mathrm{pH}$ of duck egg. The study used a completely randomized design of factorial pattern $4 \times 4$ with 4 replications. The treatment is as follows: The first factor is the concentration of onion dayak extract (A), consisting of: $\mathrm{A} 0=$ Eggs storage placed at room temperature; $\mathrm{A} 1=10 \%$ concentrated of dayak onion extract; $\mathrm{A} 2=$ $20 \%$ concentrated of dayak onion extract; A3 $=30 \%$ concentrated of dayak onion extract; The second factor is the length of storage (B) consists of: $\mathrm{B} 0=7$ days. $\mathrm{B} 1=14$ days. $\mathrm{B} 2=$ 21 days. And $\mathrm{B} 3=28$ days. Research data were analyzed using analysis of variance and continued by Tukey Test. The results showed that the concentration of dayak onion extract did not affect the reduction in egg weight, but did affect the haugh unit and albumen $\mathrm{pH}$. Egg weight reduction ranged from 0.92-1.02. Haugh unit and $\mathrm{pH}$ of albumen at $10 \%$ and $30 \%$ concentration of dayak onion extract did not differ, while the $0 \%$ concentration differed from all other treatments. Interaction effects between concentration of dayak onion extract and length storage were also significant for egg weight loss, Haugh unit, and $\mathrm{pH}$ of albumen. It is recommended that for preserving duck eggs, it is better to use a concentration of $30 \%$ onion extract.
\end{abstract}

Keywords: duck eggs, dayak onion, length sorage, haugh unit, $\mathrm{pH}$

Received 06 October 2019 | Revised 20 November 2019 | Accepted 14 March 2020

\section{Introduction}

Eggs are one of the most perfect food ingredients. These foods contain complete nutrients including protein, fat, vitamins and minerals. Fresh eggs are eggs that have just been laid by the nest and have short shelf life. If left in the open air (room temperature) only last 10-14 days. After this period the eggs undergo changes in the direction of damage such as the evaporation of

\footnotetext{
*Corresponding author at: Universitas Islam Kalimantan Muhammad Arsyad Al Banjari, Jl. Adhyaksa, Kayutangi 1 Jalur 2 No. 2, Sungai Miai, Kec. Banjarmasin Utara, Kota Banjarmasin, Kalimantan Selatan, 70123, Indonesia

E-mail address: aamgunawan@yahoo.com
} 
water content through the pores of the egg shell resulting in reduced egg weight, changes in chemical composition and the occurrence of dilution of the egg contents [7]. The storability of duck eggs is very short so it needs special treatment on the duck eggs to be stored longer. One treatment to maintain the quality of duck eggs is preservation. Preservation is very important to prolong the shelf life of eggs and maintain egg quality. The preservatives used are natural and safe preservatives [10]. The purpose of preserving eggs is to be able to maintain the quality of eggs and extend the storage period of eggs, the main purpose of preserving eggs is to prevent the evaporation of water and inhibit the release of $\mathrm{CO}_{2}$ from the egg's contents and inhibit microbial activity and propagation. Preservation of fresh eggs in principle is to prevent the evaporation of water and gas in the eggs [4]. To maintain the freshness of the quality of egg contents in the long run, appropriate handling techniques are needed so that the nutritional value of eggs remains good, namely by preservation. The method of preserving eggs can be done in various ways. One of them by dipping into the solution. This method is useful for reducing water evaporation from eggs. Lime water and water glass are materials that are often used [12].

Efforts to maintain the quality of eggs starting from the eggs coming out of the body (new laid eggs) until the eggs are in the hands of consumers are felt to be still lacking. Although breeders (producers) have produced quality eggs, but this quality will not last long, if the eggs are not given special treatment because of the nature of eggs that are easily damaged by microbial activity, evaporation of water from the eggs and others.

Dayak onions are plants that have antibacterial activity. Secondary metabolites in Dayak onions that can provide antibacterial activity include flavonoids, phenols, glycosides, triterpenoids, and anthraquinones. The test results showed that the ethanol extract of Dayak bulbs can inhibit the growth of many bacteria, including Bacillus subtilis, Streptococcus pneumoniae, Staphylococcus epidermis, Escherichia coli, Micrococcus luteus, MRSA, Propionibacterium acnes, Samonella typhi, Staphylococcus aureus [8]. Chemical content contained in Dayak onions consists of alkaloid compounds, glycosides, flavonoids, phenolics, sponins, triterpenoids, tannins, quinones and steroids that can be used as raw materials for medicines [11]. Boiled water or juice of Dayak bulbs is traditionally believed to have various benefits, including as a cure for breast cancer, high blood pressure (hypertension), diabetes (diabetes mellitus), chole/sterol, and ulcers [5]. As an anti-microbial herb [9].

Several other studies report that Dayak onions contain tanners (tannins) which can function to cover tiny holes in the surface of the eggshell. Tannin is a vegetable tanner that can close the pores of eggshells [15]. Preservation of eggs using Dayak onions has never been done so far. Therefore it is necessary to conduct a study to determine the effect of the use of extract of Dayak onion (Eleutherine palmi folia (L.) Merr) and storage time on several indicators of egg quality such as depreciation of egg weight, haugh unit and albumen $\mathrm{pH}$ on duck eggs. 


\section{Materials and Methods}

\subsection{Material and Tool}

Materials and tools were used in this research consist of 64 eggs aged one day, 1,000 $\mathrm{g}$ onion dayak, 4,000 $\mathrm{ml}$ water, calipers, $\mathrm{pH}$ meters, digital scales, thermometers, basins, and plastic containers.

\subsection{Methods}

This study uses a completely randomized factorial design of $4 \times 4$ each with 4 replications. The treatment is as follows:

The first factor is the concentration of Dayak onion extract (A), consisting of:

$\mathrm{A} 0=$ No treatment or eggs left at room temperature;

A1 = Egg soaked in Dayak extract 10\% concentrate;

A2 = Egg soaked in Dayak extract $20 \%$ concentrate;

A3 = Eggs marinated in Dayak onion extract 30\% concentrate;

The second factor is storage time (B) consisting of:

$\mathrm{B} 0=$ Egg is stored for 7 days.

B1 = Eggs are stored for 14 days.

B2 $=$ Eggs are stored for 21 days.

B3 = Eggs are stored for 28 days.

\subsection{Research Implementation}

\subsubsection{Place and time}

The study was conducted at the Laboratory of Animal Husbandry, Lambung Mangkurat University, Banjarbaru. The implementation time is from the beginning of September to the end of September 2017.

\subsubsection{Implementation}

\section{A. Preparation of dayak onion extract}

For the manufacture of $10 \%$ concentration of dayak onion extract, $144 \mathrm{~g}$ of dayak onion is cut into small pieces and heated in a pan filled with $1,180 \mathrm{ml}$ water to reach $40{ }^{\circ} \mathrm{C}$. Then let stand for 24 hours to cool and settle. $144 \mathrm{~g}$ of dayak onions is obtained from $10 \%$ water $(120 \mathrm{ml} \mathrm{x}$ 1.2) and $1,180 \mathrm{ml}$ is obtained from $1200 \mathrm{ml}$ of water minus $120 \mathrm{ml}$ of water. After 24 hours, the solution is filtered to separate the water with pieces of dayak onions. The process is then repeated for the production of dayak onion extract concentrations of $20 \%$ and $30 \%$. For a 
concentration of $20 \%$, use $288 \mathrm{~g}$ of dayak onions and $960 \mathrm{ml}$ of water and a concentration of $30 \%$ using $432 \mathrm{~g}$ of dayak onions and $840 \mathrm{ml}$ of water.

\section{B. Soaking eggs}

A total of 16 eggs per treatment were put into 4 containers that had been filled with Dayak onion extract and left for 24 hours. Soaking eggs are then stored in a place that has been prepared. Observations were made on the 7 th, 14th, 21 st and 28 th days.

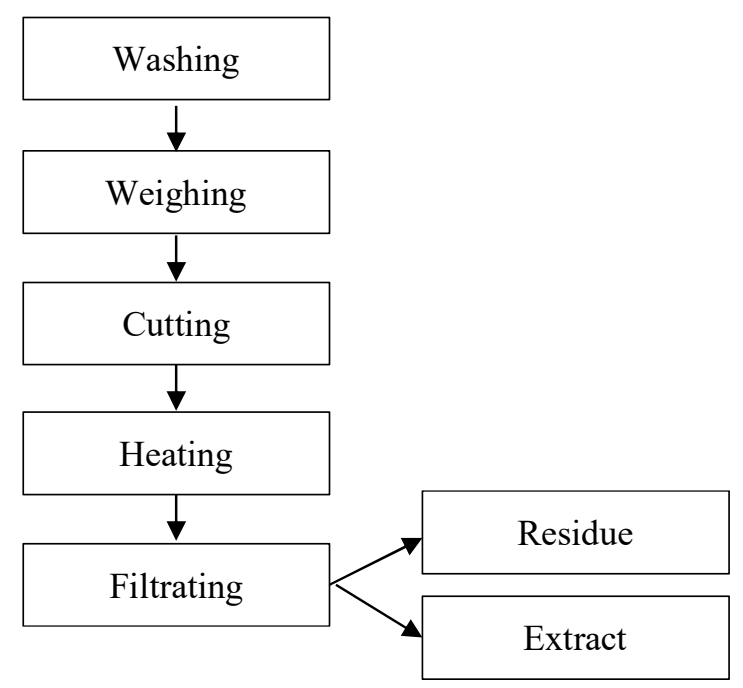

Figure 1. Flow Chart of Dayak Onion Extract Making

\subsubsection{Observed variables}

\section{A. Depreciation of egg weight}

The cleaned eggs were weighed for each treatment as initial weight and then immersed in the treatment of Dayak extract concentrations and stored according to the time of observation. Before observation, the eggs are weighed again to get the final weight. Depreciation value of egg weight is expressed in percent and is calculated by the formula:

$$
P B T=\frac{\text { initial weight }(\mathrm{g})-\text { final weight }(\mathrm{g}) \times 100 \%}{\text { initial weight }(\mathrm{g})}
$$

Information :

$\mathrm{PBT}=$ depreciation of egg weight

\section{B. Haught Unit (HU)}

Done by weighing whole eggs. Then the egg is broken on a glass plate and then the albumen is measured by inserting a measuring device (calipers) in the thick albumen area. To obtain the value the following equation is made [19]:

$$
H U=100 \log [\mathrm{H}-1.7 \mathrm{~W} 0.37+7.6]
$$


$\mathrm{HU}=$ Haugh unit

$\mathrm{H}=$ Observed height of the albumen in $\mathrm{mm}$

$\mathrm{W}=$ Weight of egg $(\mathrm{g})$

\section{C. pH of albumen}

The measurement of albumen $\mathrm{pH}$ is carried out using a $\mathrm{pH}$ meter by dipping the $\mathrm{pH}$ meter on the albumen. Next, the value shown by the $\mathrm{pH}$ meter is seen

\subsection{Data Analysis}

The data obtained were analyzed using analysis of variance in accordance with the Completely Randomized Design (CRD) of factorial patterns and treatments that gave real effect were further tested using the Tukey test [6].

\section{Results and Discussion}

\subsection{Depreciation of Egg Weight}

The results of the study of duck egg depreciation with the effect of immersion of dayak extract at several concentration levels during the room temperature storage period can be seen in Table 1.

Table 1. The Effect of Dayak Onion Extract Concentration and Storage Duration on Duck Egg Depreciation

\begin{tabular}{|c|c|c|c|c|c|}
\hline \multirow{2}{*}{$\begin{array}{l}\text { Dayak Onion } \\
\text { Extract } \\
\text { Concentration }\end{array}$} & \multicolumn{4}{|c|}{ Length of Storage (Days) } & \multirow{2}{*}{ Average \pm SEM } \\
\hline & 7 & 14 & 21 & 28 & \\
\hline $0 \%$ & 0.67 & 1.01 & 1.07 & 1.34 & $1.02 \pm 0.06$ \\
\hline $10 \%$ & 0.76 & 0.89 & 0.95 & 1.14 & $0.94 \pm 0.04$ \\
\hline $20 \%$ & 0.65 & 0.69 & 0.89 & 1.50 & $0.93 \pm 0.09$ \\
\hline $30 \%$ & 0.54 & 0.75 & 0.94 & 1,43 & $0.92+0.08$ \\
\hline Average + SEM & $0.66 \pm 0.03^{\mathrm{a}}$ & $0.84 \pm 0.04^{\underline{b}}$ & $0.96 \pm 0.0 .03^{\underline{c}}$ & $1.35 \pm 0.05^{\underline{\mathrm{d}}}$ & \\
\hline
\end{tabular}

The results of the analysis of variance showed that the concentration of dayak onion extract did not significantly affect the weight loss of duck eggs during room temperature storage. Although it was seen that the higher concentration of dayak onion extracts, the weight loss of eggs decreased. This is because at the time of immersion, water containing tannin in dayak onion extract enters through the pores of duck eggs, so as to inhibit the evaporation of egg contents. [13] states that preserving whole eggs with vegetable tanners is by immersing whole eggs in a tanning liquid, as long as the eggs are soaked there will be a protein binding reaction by tannins 
causing protein denaturation and protein clumping so that the egg pores are closed and preventing water discharge. from the egg.

The results of the analysis of variance showed that the storage time had a highly significant effect $(\mathrm{P}<0.01)$ on the percentage value of duck egg depreciation. On the 7 th day observations the average egg weight shrank $0.66 \%$. Furthermore, on the 14th day of observation, the average depreciation of egg weight increased to $0.84 \%$. On the 21 st day, the average weight loss of eggs increased to $0.96 \%$. At the last observation (day 28), egg weight depreciation reached an average of $1.35 \%$. The average percentage obtained from the storage period shows that the longer the storage the depreciation of egg weight increases. Increased depletion of egg weight due to evaporation in the egg and the effect of high temperatures during storage and low humidity will accelerate the evaporation of water from the egg. This is in accordance with the opinion of [16], which states that the longer the egg's age, the decrease in egg contents occurs due to the evaporation of water from the egg so that the egg's weight can be reduced. According to [16] evaporation of water and the release of gases such as $\mathrm{CO}_{2}, \mathrm{NH}_{3}, \mathrm{~N}_{2}$ and a little $\mathrm{H}_{2} \mathrm{~S}$ as a result of the degradation of egg organic matter occurs since the egg comes out of the body through the eggshell pores and takes place continuously, causing a decrease in the quality of the albumen, air cavity formation, and reduce egg weight. Reduction in weight of duck eggs runs in balance from the beginning of storage to the end of storage. This is because the physiology process takes place rapidly at room temperature storage where the eggs undergo water evaporation and release a certain amount of $\mathrm{CO}_{2}$ so that the longer the freshness will decrease [14].

The results of the analysis of variance showed that the interaction between the concentration of dayak onion extract and storage time significantly $(\mathrm{P}<0.05)$ affected the weight loss of duck eggs. Tukey test results show that the storage time is different in all the treatment.

Freshness of eggs stored at room temperature can undergo evaporation of water and $\mathrm{CO}_{2}$ gas as respiration activities that take place during storage so as to reduce egg weight. Storage of fresh eggs at room temperature soaked with substances containing tanners can affect the activity of water evaporation so that it takes place more slowly.

The average value of depreciation in the storage period of 28 days is $1.35 \%$ smaller than the data of research [1] by using betel leaf extract on eggs. At 28 days of retention, the value of depreciation is $4.69 \%$. This data shows that the preservation using dayak onion extract is better than using betel leaf extract on egg weight depreciation variables.

\subsection{Haugh Unit (HU)}

The results of research changes in the quality of albumen in duck eggs soaked in dayak onion extract at several concentration levels during the storage period can be seen in Table 2 . 
Table 2. Average Haugh Unit Value based on Dayak Onion Extract Concentration Level and Storage Duration

\begin{tabular}{|c|c|c|c|c|c|}
\hline \multirow{2}{*}{$\begin{array}{l}\text { Dayak Onion } \\
\text { Extract } \\
\text { Concentration }\end{array}$} & \multicolumn{4}{|c|}{ Length of Storage (Days) } & \multirow[b]{2}{*}{ Average \pm SEM } \\
\hline & 7 & 14 & 21 & 28 & \\
\hline $0 \%$ & 77.47 & 69.98 & 66.34 & 62.83 & $69.15 \pm 1.51^{\mathrm{a}}$ \\
\hline $10 \%$ & 69.01 & 68.12 & 62.09 & 64.54 & $65.94 \pm 0.87^{\mathrm{b}}$ \\
\hline $20 \%$ & 69.98 & 67.95 & 63.07 & 54.77 & $63.94+1.56^{\mathrm{c}}$ \\
\hline $30 \%$ & 66.83 & 62.67 & 64.19 & 68.30 & $65.49 \pm 0.62^{\mathrm{bc}}$ \\
\hline Average+SEM & $70.82 \pm 1.12^{\mathrm{a}}$ & $67.18 \pm 0.80^{\mathrm{b}}$ & $63.92 \pm 0.68^{\mathrm{c}}$ & $62.61 \pm 1.34^{\mathrm{c}}$ & \\
\hline \multicolumn{6}{|c|}{$\begin{array}{l}\text { Description: The numbers followed by different superscript letters in the direction of the rows indicate a } \\
\text { significantly different }\end{array}$} \\
\hline SEM & tandard error & f mean & & & \\
\hline
\end{tabular}

The results of the analysis of variance showed that the concentration of dayak onion extract did not significantly affect the value of the haugh unit. The average addition of the concentration level of Dayak onion extract shows that the higher the concentration level is given, the lower the HU value produced. In line with the results of research [2] concluded that immersion of eggs with guava leaf (Psidium guajava) solution stored at $27{ }^{\circ} \mathrm{C}$ for 28 days with tannin content of $3.90 \%$ and soaking for 30 minutes was not effective to maintain protein content, Albumen Index (IPT), and Haugh Unit of Duck Egg.

The use of dayak onion extract $0 \%$ shows $\mathrm{HU}$ value of 69.15 (quality A), $10 \% \mathrm{HU}$ value of 65.94 (quality A), 20\% HU value of 63.94 (quality A) and 30\% HU value of 65.49 (Quality A). This shows that the egg quality is still high and still has a high ovomucin content. This supports the opinion of [17] which states that HU is influenced by ovomucin content found in albumen. The higher the albumen, the higher the HU value obtained. Albumen that contain fewer ovomucins will melt faster.

The results of the varian analysis showed that the storage time had a highly significant effect on the value of the duck egg haugh unit. Haugh unit is the relationship between the thickness or height of the egg albumen compared to the overall weight of the egg. Haugh units are used as a basis for measuring the egg quality index. Determination of egg quality based on the haugh unit according to United State Department of [18] standards is as follows: haugh unit value less than 60 classified as B quality, haugh unit value between 60-71 classified as A quality, and haugh units value is more than 72 classified as AA quality.

The quality of the albumen or haugh unit as a parameter of the quality of egg freshness is calculated based on albumen height and egg weight. One of the causes of decreased egg quality is due to the evaporation of $\mathrm{CO}_{2}$ in the albumen due to prolonged storage. Resulting in a gas exchange from inside and outside the egg.

The results of the analysis of variance showed that the interaction between dayak onion extract concentration and storage time had a highly significant effect $\mathrm{P}<0.01$ ) on the haugh unit value 
of duck eggs. Tukey test results showed that the concentration of dayak onion extract $10 \%$ did not differ with dayak onion extract $30 \%$, whereas in the treatment period of storage, for 7 days were different with 14 days and 21 days, while the storage time of 21 days and 28 days were not different.

\section{3. pH of Albumen}

The average results of studies of changes in $\mathrm{pH}$ of albumen in duck eggs soaked in dayak onion extract with various levels of concentration during different storage periods at room temperature can be seen in Table 3 .

Table 3. Average $\mathrm{pH}$ of Albumen Values with Dayak Onion Extract Concentration Level and Storage Duration

\begin{tabular}{cccccc}
\hline $\begin{array}{c}\text { Dayak Onion } \\
\text { Extract } \\
\text { Concentration }\end{array}$ & $\mathbf{7}$ & $\mathbf{1 4}$ & $\mathbf{2 1}$ & $\mathbf{2 8}$ & Average \pm SEM \\
$0 \%$ & 8.99 & 8.78 & 8.81 & 8.82 & $8.85 \pm 0.03^{\mathrm{a}}$ \\
$10 \%$ & 8.73 & 8.79 & 8.76 & 8.51 & $8.70 \pm 0.04^{\mathrm{b}}$ \\
$20 \%$ & 8.30 & 8.72 & 8.70 & 8.45 & $8.54 \pm 0.06^{\mathrm{c}}$ \\
$30 \%$ & 8.38 & 8.44 & 8.74 & 8.52 & $8.52 \pm 0.05^{\mathrm{c}}$ \\
Average $\_$SEM & $8.60 \pm 0.08^{\mathrm{b}}$ & $8.68 \pm 0.05^{\mathrm{ab}}$ & $8.75 \pm 0.02^{\mathrm{a}}$ & $8.58 \pm 0.05^{\mathrm{b}}$ & \\
\hline Description: & The numbers followed by different superscript letters in the direction of the rows indicate a \\
\\
\multicolumn{5}{l}{ SEM } \\
SEM = standard error of mean
\end{tabular}

The results of the analysis of variance showed that the concentration of dayak onion extract significantly affected the $\mathrm{pH}$ value of albumen. At a concentration of $0 \%$ dayak onion extract, the $\mathrm{pH}$ value of albumen was 8.85 . At a concentration of $10 \%$ an average $\mathrm{pH}$ of 8.70 was obtained. Furthermore, at a concentration of $20 \%$ an average $\mathrm{pH}$ value of 8.54 and at a concentration of $30 \%$ obtained an average $\mathrm{pH}$ value of albumen 8.52 . The decrease in the $\mathrm{pH}$ value of albumen is probably due to the influence of the concentration of the extract of Dayak onion which can inhibit the evaporation of water and $\mathrm{CO}_{2}$ gas.

Increasing the $\mathrm{pH}$ value is usually caused by large egg pores causing evaporation of water and $\mathrm{CO}_{2}$ gas from the egg out through the pores of the egg shell so that the $\mathrm{pH}$ of the egg cannot be maintained. This is in accordance with the opinion of [20] showing that the longer the eggs are stored, the haugh units will decrease due to the dilution of the egg white caused by the evaporation of $\mathrm{CO}_{2}$ gas so that the $\mathrm{pH}$ rises and accelerates the breakdown of ovomucin.

The results of the analysis of variance showed that the storage time had a highly significant effect on the $\mathrm{pH}$ value at each treatment. This is because the longer the storage, the $\mathrm{CO}_{2}$ gas will decrease in the egg due to evaporation coming out through the pores of the egg, so the $\mathrm{pH}$ of the egg will increase. One measurement of egg quality interior is the $\mathrm{pH}$ value of albumen. The normal $\mathrm{pH}$ a newly laid eggs is between 7-8.5 [18]. [3] suggested the $\mathrm{pH}$ value of fresh eggs around 7.6. An increase in the $\mathrm{pH}$ of the albumen as a result of loss of $\mathrm{CO}_{2}$ gas in the egg. 
Table 3 shows that the higher the concentration level of dayak onion extract, the $\mathrm{pH}$ of albumen value decreases. The storage duration showed that the longer the storage, the $\mathrm{pH}$ value increased, except for 28 days storage which decreased. The results of the analysis of variance showed that the interaction between dayak onion extract concentration and storage time significantly $(\mathrm{P}<0.05)$ affected the $\mathrm{pH}$ value of albumen in duck eggs. Tukey test results showed that the concentration of dayak onion extracts differed between $0 \%$ to $20 \%$ and $0 \%$ to $30 \%$. while the storage time 7 days did not differ with 28 days.

\section{Conclusions and Suggestions}

Based on the results and discussion, it can be concluded that the concentration of dayak onion extract affects the value of haugh unit and $\mathrm{pH}$ of albumen. Storage duration affects the depreciation of egg weight, haugh unit value and $\mathrm{pH}$ of albumen. The interaction between dayak onion extract concentration and storage time affects the depreciation of egg weight, haugh unit and albumen $\mathrm{pH}$. It is recommended in preserving duck eggs, you should use a concentration of dayak extract with a level of about $30 \%$ as a preservative.

\section{REFERENCES}

[1] M. Aswar, "Pengaruh Konsentrasi Perendaman Larutan Daun Sirih (Piper Betle L.) dan Lama Penyimpanan pada Suhu Ruang terhadap Kualitas Interior Telur Ayam Ras," Skripsi, Fakultas Peternakan, Universitas Hasanuddin, Makassar, 2011.

[2] N. Azizah, M. A. Djaelani and S. M. Mardiati, "Kandungan protein, indeks putih telur (IPT) dan haugh unit (HU) telur itik setelah perendaman dengan larutan daun jambu biji (Psidium guajava) yang disimpan pada suhu $27{ }^{\circ} \mathrm{C}$," Buletin Anatomi dan Fisiologi, vol. 3, no. 1, pp. 46-55, 2018.

[3] K. A. Buckle, R. A. Edwards, G. H. Fleet and M. Wooton, Ilmu Pangan. Jakarta: Universitas Indonesia, 2009.

[4] M. A. Djaelani, "Pengaruh pencelupan pada air mendidih dan air kapur sebelum penyimpanan terhadap kualitas telur ayam ras (Gallus L.)," Buletin Anatomi dan Fisiologi, vol. 23, no. 1, pp. 24-30, 2015.

[5] R. Y. Galingging, "Potensi plasma nutfah tanaman obat sebagai sumber biofarmaka di Kalimantan Tengah,” J Pengkajian dan Pengembangan Teknologi Pertanian, vol. 10, pp. 76-83, 2007.

[6] V. Gaspersz, Metode Perancangan Percobaan. Jilid 1. Bandung: Tarsito, 1995.

[7] S. Melia, I. Juliyarsi, and Africon, "Teknologi Pengawetan Telur Ayam Ras Dalam Larutan Gelatin Dari Limbah Kulit Sapi," Fakultas Peternakan, Universitas Andalas, Surabaya, 2009.

[8] V. Mierza, D. Suryanto, and P. M. Nasution, "Skrining fitokimia dan uji efek antibakteri ekstrak etanol umbi bawang sabrang (Eleutherine palmofolia Merr.)," Prosiding Seminar Nasional, Universitas Sumatera Utara, Medan, 2011.

[9] R. Puspadewi, P. Adirestuti, and R. Menawati, "Khasiat umbi bawang dayak (Eleutherine Palmifolia (L.) Merr.) sebagai herbal antimikroba kulit," Kartika Jurnal Ilmiah Farmasi, vol. 1, no. 1, pp. 31-37, 2013.

[10] S. Rahmawati, T. R. Setyawati, A. H. Yanti, :Daya simpan dan kualitas telur ayam ras dilapisi minyak kelapa, kapur sirih dan ekstrak etanol kelopak rosella," Jurnal Protobiont, 
vol. 3, no. 1, pp. 55-60, 2014.

[11] C. A. Saptowalyono, "Bawang dayak, tanaman obat kanker yang belum tergarap," www.Kompas.com, Palangkaraya, 2008.

[12] I. W. Suardana and I. B. N. Swacita, Higien Pangan. Denpasar: Udayana University Press, 2009.

[13] S. T. Soekarto, Teknologi Penanganan dan Pengolahan Telur. Bandung: Alfabeta, 2013.

[14] F. G. Winarno and S. Koswara, Telur: Komposisi, Penanganan, dan Pengolahannya. Bogor: M-Brio Press, 2002.

[15] E. Wulandari, O. Rachmawan, A. T. Taofik, N. Suwarno and A. Faisal, "Pengaruh ekstrak dauh sirih (Pipper Betle. L) sebagai perendaman telur ayam ras konsumsi trehadap daya awet pada penyimpanan suhu ruang," Jurnal Istek, vol. 7, no. 2, pp. 163-174, 2013.

[16] Sudaryani, Kualitas Telur. Jakarta: Penebar Swadaya, 2003.

[17] W. J. Stadelman and O. J. Cotterill, Egg Science and Technology. Fourth Edition. New York: The Haworth Press, 1995.

[18] United States Department of Agriculture, Egg Grading Manual, Washington, 2000.

[19] K. N. Monira, M. Salahuddin and G. Miah, "Effect of breed and holding period on egg quality characteristics of chickens," International Journal of Poultry Science, vol. 2, no. 4, pp. 261-263, 2003.

[20] D. Purwaningsih, M. A. Djaelani, and T. R. Saraswati, "Kualitas telur ayam ras setelah pemberian olesan lidah buaya (aloe vera) dan lama penyimpanan waktu yang berbeda," Buletin Anatomi dan Fisiologi, vol. 24, no. 1, pp. 13-20, 2016. 